\title{
Streamflow droughts in the Iberian Peninsula between 1945 and 2005: spatial and temporal patterns
}

\author{
J. Lorenzo-Lacruz, E. Morán-Tejeda, S. M. Vicente-Serrano, and J. I. López-Moreno \\ Pyrenean Institute of Ecology (CSIC), Department of Geoenvironmental Processes and Global Change, Campus de Aula Dei, \\ P.O. Box 202, Zaragoza 50080, Spain
}

Correspondence to: J. Lorenzo-Lacruz (jlorenzo@ipe.csic.es)

Received: 11 June 2012 - Published in Hydrol. Earth Syst. Sci. Discuss.: 2 July 2012

Revised: 3 December 2012 - Accepted: 3 December 2012 - Published: 17 January 2013

\begin{abstract}
In this study we analyzed the spatiotemporal variability of streamflow droughts in the Iberian Peninsula from 1945 to 2005. Streamflow series belonging to 187 homogeneously distributed gauging stations across the study area were used to develop a standardized streamflow index (SSI), which facilitated comparison among regimes and basins, regardless of streamflow magnitudes. A principal component analysis was performed to identify homogeneous hydrological regions having common features based on the temporal evolution of streamflows. Identification of drought events was carried out using a threshold level approach. We assessed the duration and magnitude of drought episodes and the changes that occurred between two contrasting periods for each hydrological region. The results showed a trend toward increased drought severity in the majority of regions. Drought duration, magnitude and spatial coverage were found to depend mainly on climatic conditions and the water storage strategies in each basin. In some basins these strategies have altered river regimes, and in others created a high level of dependence on storage and water transfer rates.
\end{abstract}

\section{Introduction}

Among natural hazards, drought is one of the most damaging and affects more people than any other (Obasi, 1994), causing negative ecological, economic, agricultural, social and political impacts. Many European countries have experienced problems arising from droughts during recent decades, including restrictions on water usage for urban consumption and leisure, reductions in electricity supply (European Environmental Agency; EEA, 2001), crop production losses and increased forest fires. The global economic impact of the 2003 drought in France, Italy, Germany, Spain, Portugal, Austria, Hungary, Estonia and Slovakia was estimated to be approximately 13.1 billion $€$ (COPA-COGECA, 2003).

Drought has been defined as the naturally occurring phenomenon that exists when precipitation has been significantly below normal recorded levels, causing serious hydrological imbalances that adversely affect production systems (UN Secretariat General, 1994). Contrary to other climaterelated hazards such as floods, which are generally restricted to small regions and have well-defined temporal intervals, droughts are difficult to quantify and pinpoint in time and space, as they develop slowly and last for long periods (Vicente-Serrano, 2006a). Conceptually, droughts have been classified into four categories (meteorological, agricultural, hydrological and socioeconomic) based on the system affected and the time scale in which the drought impacts become evident (Wilhite and Glantz, 1985).

A hydrological drought is defined as a decrease in the availability of water in all its forms within the land phase of the hydrological cycle, which includes streamflow, groundwater, reservoirs and lakes. Amongst these, streamflow is the most significant variable in terms of quantity. Because of the dependence of energy production, irrigation, riparian ecosystems and public water supply on river discharges, most studies have focused on streamflow droughts, which occur when relatively low flows are recorded (Tallaksen et al., 2009).

Streamflow is an integrated response to basin inputs (climate), water transfer, water losses by evapotranspiration, storage processes, and human interventions (Fleig et al., 2011; López-Moreno et al., 2013). Previous studies have reported that the response of basins to precipitation deficiency 
is highly variable, and mainly depends on the physiographic characteristics of the catchments involved (permeability, topography, land use and land cover), the climatic conditions (precipitation and evapotranspiration), and the regulation of water (Post and Jakeman, 1996; Lorenzo-Lacruz et al., 2010; López-Moreno et al., 2013). The complexity of the interactions amongst these factors may cause a discrepancy between the amount of precipitation and the status of surface and groundwater supplies. The components of the hydrological cycle interact in multiple ways in a catchment, which introduces time lags between a decline in precipitation and when this becomes evident in other components of the hydrological cycle (Vicente-Serrano and López-Moreno, 2005; Wilhite and Glantz, 1985; Lorenzo-Lacruz et al., 2010). For example, the most severe hydrological droughts do not always occur in areas with the lowest effective rainfall. On the contrary, they usually depend on the demand for water, the water management strategies, the land cover and the meteorological conditions in the headwaters (EEA, 2001). As the water remains for shorter time in the upper reaches of unregulated rivers than in the middle or lower reaches, drought intensity often varies with topographic location and time in the basin (Mudelsee, 2007; Pandey et al., 2008).

The assessment and characterization of historical droughts has become essential in management of fresh water (Mishra and Singh, 2010), and application of the information obtained to the design of water management plans may compensate for the losses resulting from drought episodes (Quiroga et al., 2011). There is a general agreement about the need for research into streamflow droughts and regime types (Wilhite et al., 2007). Several studies have assessed streamflow droughts in Europe (Tallaksen et al., 1997; Hisdal et al., 2001; Stahl, 2001; Gudmundsson et al., 2011), and developed a relatively homogeneous methodological framework related to their definition and characterization. The threshold level approach, based on annual, monthly and daily records, has been widely used to define drought events (Yevjevich, 1967; Dracup et al., 1980; Tallaksen et al., 1997; Fleig et al., 2006; Timilsena et al., 2007). Using a selected threshold level, the three key characteristics that distinguish one drought from another (magnitude, duration and spatial coverage) can be inferred (Wilhite and Glantz, 1985; Tallaksen et al., 2009). Based on the above characteristics, this approach allows regions with homogeneous drought behavior to be defined (Stahl and Demuth, 1999; Fleig et al., 2011).

In this study we analyzed the spatiotemporal patterns of streamflow droughts in the Iberian Peninsula (IP) from 1945 to 2005 in both regulated and unregulated basins. This study was driven by the crucial importance of drought analysis in the IP as a consequence of the economic losses caused by droughts in this area (Iglesias et al., 2007), the rising demand for water in recent years (Albiac et al., 2003; Lorenzo-Lacruz et al., 2010), the recurrence of dry episodes that increase the vulnerability of society and the economy, and the complexity of water management in the area (Quiroga et al., 2011).
An increased knowledge of the behavior of river discharges under drought conditions, and the various drought typologies and their characteristics, is necessary for implementation of effective and sustainable water management strategies in the IP.

The objectives of the study were to (i) establish a regionalization of the IP based on the evolution of the streamflows; (ii) analyze the streamflow drought characteristics of each hydrological region; and (iii) investigate if there have been changes in streamflow drought characteristics (duration, magnitude and spatial coverage) during the second half of the 20th century. This study represents a novel contribution to the analysis of streamflow droughts in the IP: we have addressed this issue at the regional spatial scale (including the entire IP and its main river basins, regulated and unregulated), using a long-term dataset (1945-2005).

\section{Study area}

The IP covers $583254 \mathrm{~km}^{2}$ and has a very contrasting relief. The mountain ranges mainly run from west to east, and in some cases reach altitudes of approximately $3000 \mathrm{~m}$ a.s.l., resulting in the region having the second highest mean altitude (637 m a.s.1.) in Western Europe. These mountains have influenced the river network and the spatial configuration of the major basins of rivers flowing towards the Atlantic Ocean (the Miño, Duero, Tajo, Guadiana and Guadalquivir basins) and the Mediterranean Sea (the Segura, Júcar and Ebro basins) (see Fig. 1). The location and topography of the IP, together with the effects of large atmospheric circulation patterns (López-Bustins et al., 2008) generate a southeast to northwest gradient in annual precipitation (De-Castro et al., 2005; González-Hidalgo et al., 2011) (see Fig. 1). Precipitation is concentrated mainly in winter (40\% of annual precipitation), and varies from less than $300 \mathrm{~mm} \mathrm{yr}^{-1}$ (in the southeast corner, e.g. the Murcia region) to more than $1500 \mathrm{~mm} \mathrm{yr}^{-1}$ (in the northwest, e.g. the Galicia region). These patterns cause large variability in the duration and frequency of droughts among the various regions of the IP (Rico-Amorós, 2004; Vicente-Serrano, 2006b). Winter floods dominate the flow regime typical of Mediterranean rivers. Higher inter-annual variability of streamflow results in long supra-seasonal droughts (Boix et al., 2010).

River basins in the northern sector of the Atlantic watershed produce abundant yields, with mean annual flows (measured at the most downstream streamflow gauges) of $10570 \mathrm{hm}^{3} \mathrm{yr}^{-1}$ (cubic hectometers) for the Miño River, $13788 \mathrm{hm}^{3} \mathrm{yr}^{-1}$ for the Duero River, and $12350 \mathrm{hm}^{3} \mathrm{yr}^{-1}$ for the Tajo River. In contrast, rivers in the southern sector of the Atlantic watershed (the Guadiana and Guadalquivir rivers) have modest mean annual streamflows of $4039 \mathrm{hm}^{3} \mathrm{yr}^{-1}$ and $3780 \mathrm{hm}^{3} \mathrm{yr}^{-1}$, respectively. Streamflows in basins in the Mediterranean watershed (the Segura, Júcar and Ebro basins) are generally low; except for the Ebro 
basin, which has abundant flow (mean $12279 \mathrm{hm}^{3} \mathrm{yr}^{-1}$ ) that is generated in the Cantabrian Range and the Pyrenees. The uneven distribution of water resources within the IP and the rising demand for water have resulted in conflicts among users and regions (Quiroga et al., 2011). The increasing frequency of drought events in the IP since the 1970s (VicenteSerrano et al., 2006a; Iglesias et al., 2007) have resulted in the construction of a complex network of dams and channels to optimize the use of available water resources. This is especially the case in the southern basins, where significant regulation capacity has been developed during the last $60 \mathrm{yr}$ (Arroyo-Ilera, 2007). The intensive regulation of river systems in the IP is reflected in an increase in the number of major reservoirs constructed during the 20th century (from 58 in 1900 to 1195 in 2000), which together account for a total storage capacity of $56500 \mathrm{hm}^{3}$ (Berga-Casafont, 2003). This capacity is approximately equal to the mean annual streamflow of the 8 major rivers of the IP $\left(55850 \mathrm{hm}^{3} \mathrm{yr}^{-1}\right)$.

\section{Dataset and methodology}

\subsection{Streamflow records}

To create a representative streamflow database for the entire IP, streamflow data from 1460 gauging stations located across the study area were obtained from water agencies of Spain (Centro de Estudios Hidrográficos, Agència Catalana de l'Aigua, Agencia Andaluza del Agua and Augas de Galicia) and Portugal (Sistema Nacional de Informaçâo de Recursos Hídricos). Daily streamflow data for the IP were obtained from measurements of the daily water level at each gauging station. The monthly river discharge at each station was integrated from the average daily discharge. We conducted our analysis using monthly data due to the characteristics of hydrological droughts. Drought episodes are recognized to be difficult to pinpoint in time and space, the effects grow slowly in magnitude and their impact can accumulate over long periods of time (Mishra and Singh, 2010). For these reasons we considered monthly data more suitable for drought characterization than daily data.

The quality and length of the series was highly variable. Only the longest and most complete records were used to represent the major basins throughout the IP. Each record had to cover at least $50 \mathrm{yr}$. The monthly streamflow series used covered the period from 1945 to 2005, with the aim of including any changes resulting from the intensive river regulation that took place in the second half of the 20th century. In total, 187 monthly streamflow series were selected, based on their record length and the percentage of data gaps. Time series with $10 \%$ or more of the data missing for the total period of the series were excluded. Infilling of missing data was performed by linear regression analysis, and flow records at neighboring stations were used as the independent variables. The minimum Pearson's correlation coefficient between the series in the model was set at $R=0.8$. More details about the creation and validation of the database are provided in Lorenzo-Lacruz et al. (2012).

\subsection{Standarization of streamflow series}

To obtain a hydrological index that enabled comparison of streamflow series in time and space, regardless of the magnitude of the series and the river regimes involved, we transformed the monthly streamflow series into standardized zscores. It is very common that hydrological series are not normally distributed, and consequently must be adjusted to other probability distributions (Gámiz-Fortis et al., 2010; VicenteSerrano et al., 2011) to facilitate standardization. Several streamflow indices have recently appeared in the literature (e.g. Shukla and Wood, 2008; Nalbantis and Tsakiris, 2009); however, the accuracy of the indices is limited due to the adjustment to a unique probability distribution. In order to obtain a reliable standardized streamflow index (SSI) that encompasses the large variability in the statistical properties of the monthly data, the series were fitted to the most suitable probability distribution, according to the minimum orthogonal distance (MD) between the sample L-moments at site $i$ and the L-moment relationship for a specific distribution selected from the general extreme value (GEV), the Pearson type III (PIII), the log-logistic, the lognormal, the generalized Pareto and the Weibull distributions. For each streamflow series we calculated six SSI series, corresponding to each of the six probability distributions used, and we selected the one which showed the most robust adjustment (minimum orthogonal distance in a L-moments diagram). Once $F(x)$ (the cumulative distribution function) is identified, the SSI (in $z$-scores) can easily be calculated following, for example, the classical approximation of Abramowitz and Stegun (1965). More datails about the SSI calculation can be found in Vicente-Serrano et al. (2011).

\subsection{Regionalization}

To characterize the regional patterns of streamflow drought evolution across the IP, a regionalization procedure was performed prior to assessment of the streamflow drought characteristics. This was possible because of the extensive scale of the analysis and the large number of SSI series utilized. Previous studies focused on this issue have used cluster analysis to define coherent regions having homogenous drought behavior (Stahl and Demuth, 1999; Fleig et al., 2011). In this research we used principal component analysis (PCA) in S mode to define regions where the temporal variation of the hydrological variables (standardized stramflow index evolution at the 187 gauging stations) had the same pattern (the observation stations were the variables, and the time observations the cases). The PCA technique is widely used by hydrologists to analyze the spatiotemporal variability of hydrological variables (Preisendorfer, 1988; Kalayci and Kahya, 


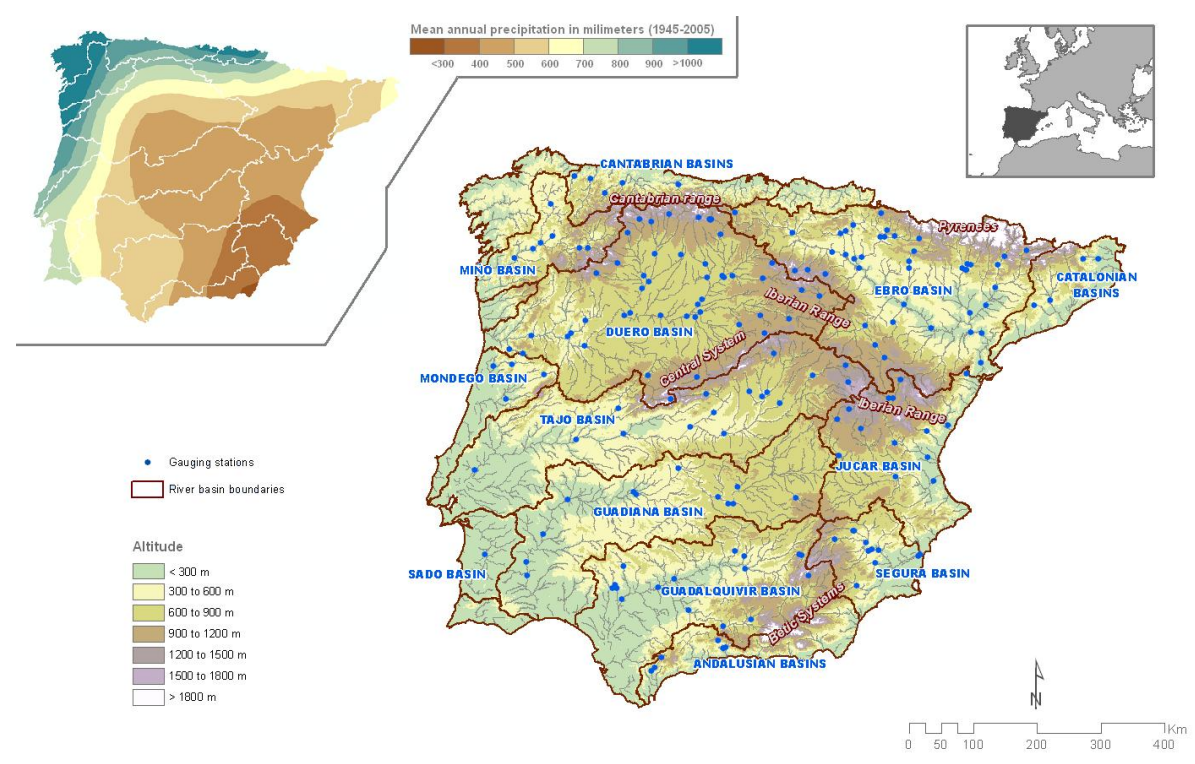

Fig. 1. The Iberian Peninsula: topography and location of the gauging stations used in the study distributed by mayor basins. Upper left corner: distribution of the mean annual precipitation for the study period (1945-2005). Upper right corner: Iberian Peninsula location map.

2006; Kahya et al., 2008; Morán-Tejeda et al., 2011; Peterson et al., 2011); it allows for retention of common features of the samples and identification of local peculiarities. Using this approach we obtained an additional non-correlated set of variables that were the linear combinations of the originals. The components were rotated to redistribute the explained variance and to obtain more physically robust patterns. This transformation was done by varimax rotation (White et al., 1991), which is the most recommended approach for this task (Jollife, 1990). The coefficients of such combinations ("loading factors") represent the correlations of the principal component with each original variable (the SSI series for each gauging station). Identification of the maximum loading factor enabled us to classify each gauging station into the resulting groups. Drought analysis and characterization were therefore based on the hydrological regions defined by the PCA. The selection of the principal components was based on the explained variance. In order to give consideration to a new principal component it must explain more than $1.5 \%$ of the total variance. We also included information about the properties of the catchments represented by each PC; the physiographic characteristics of the basins included in each hydrological region were derived using a $100 \mathrm{~m}$ digital elevation model (mean altitude and mean slope of the basins), whereas the mean annual discharge and the Impoundment Ratio were calculated using water agencies data.

\subsection{Drought characterization}

In order to define drought events, a threshold level that does not vary in time and space, since records are standardized, was applied to the SSI series (Yevjevich, 1967; Tallaksen et al., 1997; Hisdal et al., 2004; Tallaksen et al., 2009). The threshold level was set up at the $20 \%$ of cumulative probability ( $\mathrm{SSI}=-0.84$, given the standardized characteristic of the variable), and a drought event was thus registered when the monthly SSI fell below that level (van Loon et al., 2010). Based on this threshold, streamflow droughts were characterized using the following parameters: (i) drought duration, (ii) drought magnitude, and (iii) drought-affected area (Fig. 2). (i) Drought duration: The duration $d_{n}$ of a given drought event $e_{n}$ was defined as the consecutive and uninterrupted time steps (one or more months) with an observed streamflow (SSI) below P20 at a specific gauging station. (ii) Drought magnitude: The accumulated deficit volume $v_{n}$ was defined as the sum of the deficit volumes generated during an uninterrupted number of months $\left(d_{n}\right)$, delimiting a drought event $e_{n}$ expressed as accumulated deficits of the SSI. (iii) Droughtaffected area: To estimate the drought-affected area we delimited the catchments draining to the respective gauging station. The areas affected by droughts for those rivers with more than one delimited sub-basin referred only to the subbasin area between the gauging stations, not from the gauging station to the headwaters. We subsequently used a conditional function to indicate the drought occurrence and type (SSI $>-0.84=$ no drought $;-1.65<$ SSI $<-0.84=$ drought; SSI $<-1.65$ (5th percentile) $=$ severe drought). To compute the areas draining to a specific gauging station that registered drought conditions (SSI $<-0.84$ for drought, and SSI $<-1.64$ for severe drought), we evaluated the SSI values of each gauging station at each time step in relation to the above function. In this way we estimated the drainage areas that contributed to observed droughts at particular locations (gauging stations). 


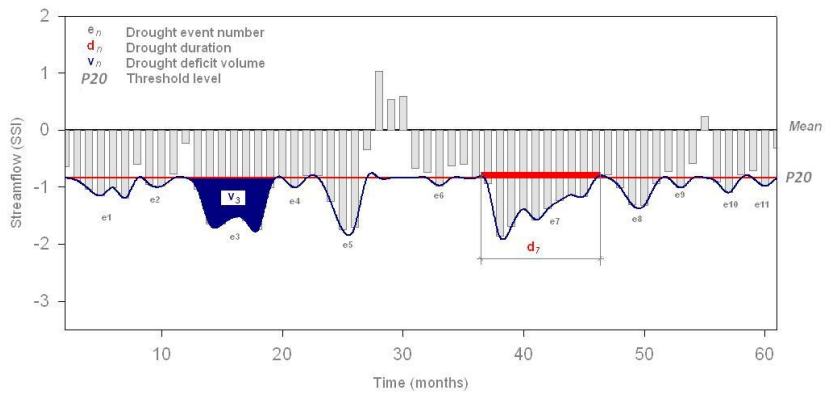

Fig. 2. Drought definition sketch.

\subsection{Correlation analysis}

In the last section of the study we performed several correlation analyses between the principal components and various factors, which we considered appropriate to explain the hydrological regionalization obtained in Sect. 4.1. Among these factors we included the variability of the North Atlantic Oscillation (NAO), which has been proved to be the dominant pattern influencing streamflows in western Europe and in the Iberian Peninsula (Lorenzo-Lacruz et al., 2011), and the Western Mediterranean Oscillation (WeMO) (Martín-Vide and López-Bustins, 2006). Since streamflow droughts are related to climate variability, we correlated a meteorological drought index, the Standardized Precipitation Index (McKee at al., 1993), with selected principal components to assess the time lags between meteorological droughts and streamflow droughts. Finally we correlated the streamflow of the Tajo-Segura water transfer (in SSI units) with the SSI evolution of the Segura basin to estimate its dependence on the water transferred.

\section{Results}

\subsection{Streamflow-related homogeneous regions}

Figure 3 shows the distribution of the sub-basins most correlated with each principal component (PC) obtained. The boxplots indicate the range of values of the impoundment ratio (storage capacity upstream of the gauging station divided by the long-term mean annual runoff; Batalla et al., 2004), elevation, slope and annual discharge for the subbasins belonging to each PC. We considered the first ten PCs, which together explained $60 \%$ of the total variance (evolution of the SSI at 187 gauging stations); this was considered to represent a reasonable portion of the very high variability of the streamflow behavior, since the variability of Iberian monthly precipitation was summarized into 6 components (70\% of the variance, Vicente-Serrano et al., 2006b). The largest region ( $41.8 \%$ of the study area and 49 cachtments) included catchments most correlated with principal component 1 (PC1). It showed a clear spatial pattern that included sub-basins corresponding to the upper reaches of the Duero and Tajo rivers, the Jalón-Jiloca river system in the southwestern sector of the Ebro basin, and most of the Guadiana, Guadalquivir and Júcar basins. This region is characterized by moderate water yields and catchment slopes, and has a high degree of regulation. The impoundment ratio for the region indicates that the regulation capacity exceeds the annual water yield in many sub-basins. PC2 was mainly associated with a large proportion of the middle and lower reaches of the Miño, Duero and Tajo rivers, represented $26.8 \%$ of the study area and encompassed 46 cachtments. Basins in this region are located on the north Iberian plateau (> 900 m a.s.l.), where exposure to the influence of Atlantic Ocean air masses is closely related to abundant flows. The catchments correlated with PC3 occupied $6.6 \%$ of the study area and included 24 sub-basins that were interspersed with those belonging to PC2. They corresponded to headwaters of the Miño and Duero river basins and some of their tributaries, which are fed by the Central System and the Mountains of Leon (the westernmost foothills of the Cantabrian Range). This region has a very low level of regulation and moderate streamflow volumes. The sub-basins most correlated with PC4 covered $12.7 \%$ of the study area (25 cachtments), and included the majority of the Cantabrian basins, and the main course of the Ebro River and its tributaries flowing from the Atlantic Pyrenees. PC4 was characterized by abundant water yields, and the high altitude and steep slopes of the Cantabrian basins, the headwaters of the Ebro River and the Pyrenean tributaries. The sub-basins represented by PC5 (5.5\% of the study area and 14 cachtments) corresponded to river systems flowing from the central Pyrenees. This region has the steepest slopes and the highest altitudes. PC6 represented the Andalusian basins and the right bank tributaries of the Guadalquivir basin. This region covers $1.5 \%$ of the study area (13 cachtments), and is characterized by low discharges and a considerable degree of regulation. PC7 and PC8 were correlated with contrasting parts of the Segura basin. PC7 (1.64\% of the study area and 5 cachtments) was related to sub-basins that directly receive water transferred from the headwaters of the Tajo basin, while PC8 $(1.7 \%$ of the study area and 5 cachtments) represents the Segura basin sub-systems not directly influenced by water transfer. Both PC7 and PC8 were characterized by changes resulting from extreme water regulation. PC9 encompassed $1 \%$ of the study area and included all of the Catalonian basins (4). PC10 (0.5\% of the study area and 2 cachtments) was correlated with the most upstream stations of the Tajo and Júcar rivers.

\subsection{Temporal evolution of drought}

Figure 4 shows the temporal evolution of the scores of PCs $1-5$, and the factorial loadings (correlations) between each $\mathrm{PC}$ and the monthly SSI at each gauging station. PC1 explained $12.8 \%$ of the total variance and showed a low temporal frequency in the alternation between moist and dry 


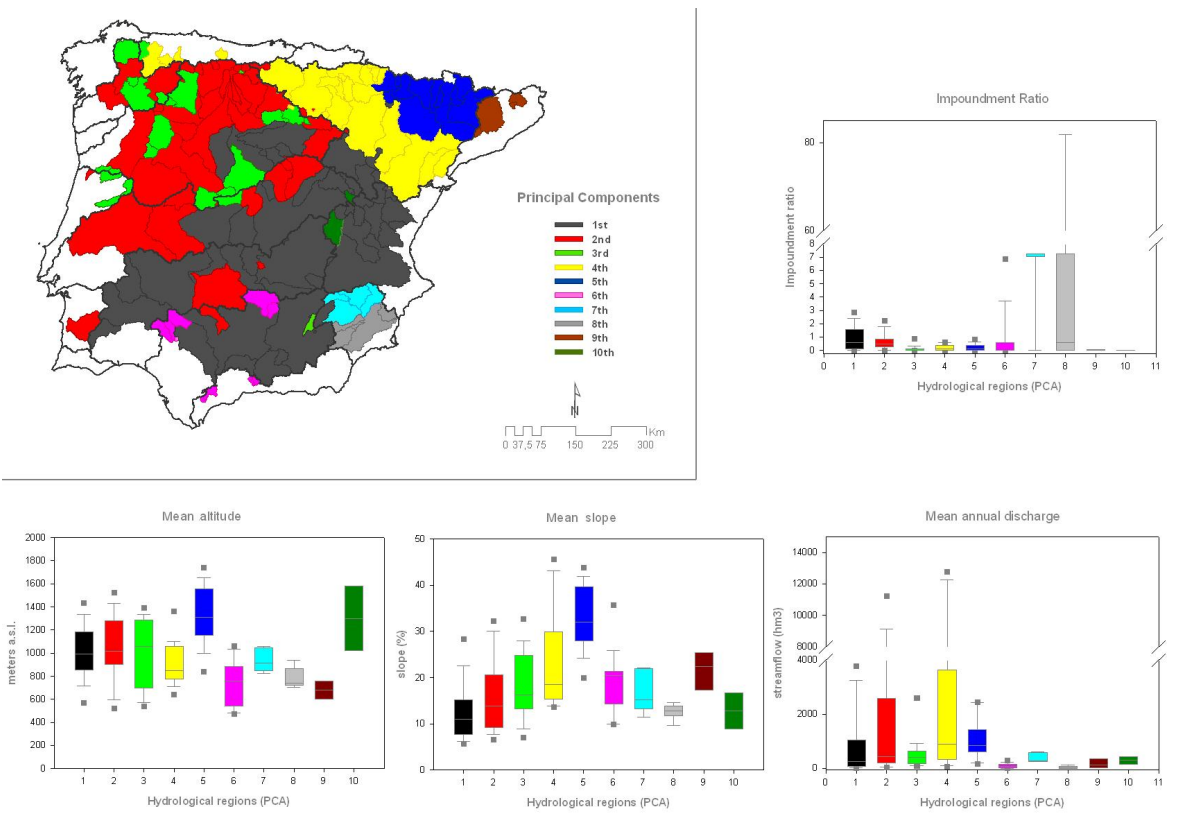

Fig. 3. Spatial distribution of the highest loadings sub-basin from each principal component. Box-plots show the mean altitude, mean slope, mean annual discharge and the impoundment ratio of every sub-basin included in each hydrological region.

periods. Two contrasting periods were evident in the temporal evolution of PC1: a humid period from 1945 to 1980 with sporadic drought episodes during the 1950 s, and a following dry period that lasted until 2005. Within the latter, three main droughts occurred: one in the early 1980s, one in the middle of the 1990s that lasted for $5 \mathrm{yr}$ (the longest and most severe hydrological drought in the IP since records began), and one at the beginning of the 21st century (with 2003 having the driest conditions). The correlations between this temporal signature and the streamflow series were very high for those rivers with headwaters and upper reaches located in the southern Iberian range (the Tajo, Júcar, Guadiana rivers, and the Jalón-Jiloca system).

PC2 explained $11.56 \%$ of the variance and was associated with a relatively high temporal frequency in the occurrence of dry and moist periods, which occurred almost annually. Two contrasting periods were also observed for this PC. The first (from 1945 to 1965) was associated with repeated intense and intra-annual droughts that occurred almost every year, while the second (1970s to present) was associated with a reduction in the number and intensity of drought periods. This pattern was highly correlated with the lower reaches of the Miño River, the right bank tributaries of the Duero basin and the lower Tajo basin.

PC3 explained $9.5 \%$ of the variance, and also showed a high temporal frequency between dry and moist periods. The temporal evolution of PC3 showed an increase in the frequency, duration and intensity of drought episodes after the 1970s, with the most notable occurring in 1992-1994 and 2003-2005. The low reaches of the Duero basin, almost the entire Mondego basin, and the systems flowing from the Mountains of León (the Eria and Tera rivers in the Duero basin, and the Sil and Cabrera rivers in the Miño basin) were highly correlated with this PC.

PC4 explained $8.81 \%$ of the total variance. Although it was associated with a moderate frequency in the succession of dry and moist periods, its temporal evolution showed a predominance of drought episodes (which were common) over humid periods. The most intense droughts occurred in 1949, 1955 and 1990. The Cantabrian basins were moderately correlated with this component, whereas correlations increase for the main course of the Ebro River and its left bank tributaries flowing from the eastern (Atlantic) Pyrenees (the Ega, Arga and Irati rivers).

PC5 explained $4.73 \%$ of the variance and was characterized by similar frequencies of dry and moist periods. Six major drought episodes occurred during the study period: 19481950, 1957-1959, 1980, 1983-1986, 1988-1992 and 19981999. Rivers flowing from the central Pyrenees were moderately (the Aragón River system) or highly (the Segre-Cinca system) correlated with this PC.

Figure 5 shows the temporal evolution of the scores of PCs 6-10 and the factorial loadings (correlations) between each PC and the monthly SSI at each gauging station. PC6 explained $4.33 \%$ of the variance, and its temporal evolution showed two periods related to drought: in the first, from 1945 to 1975 , the droughts were of low intensity and moderate duration; whereas during the second, from 1975 to 2005, the intensity of drought episodes increased. Correlations with PC6 were weak for the rivers of the southwestern sector of 

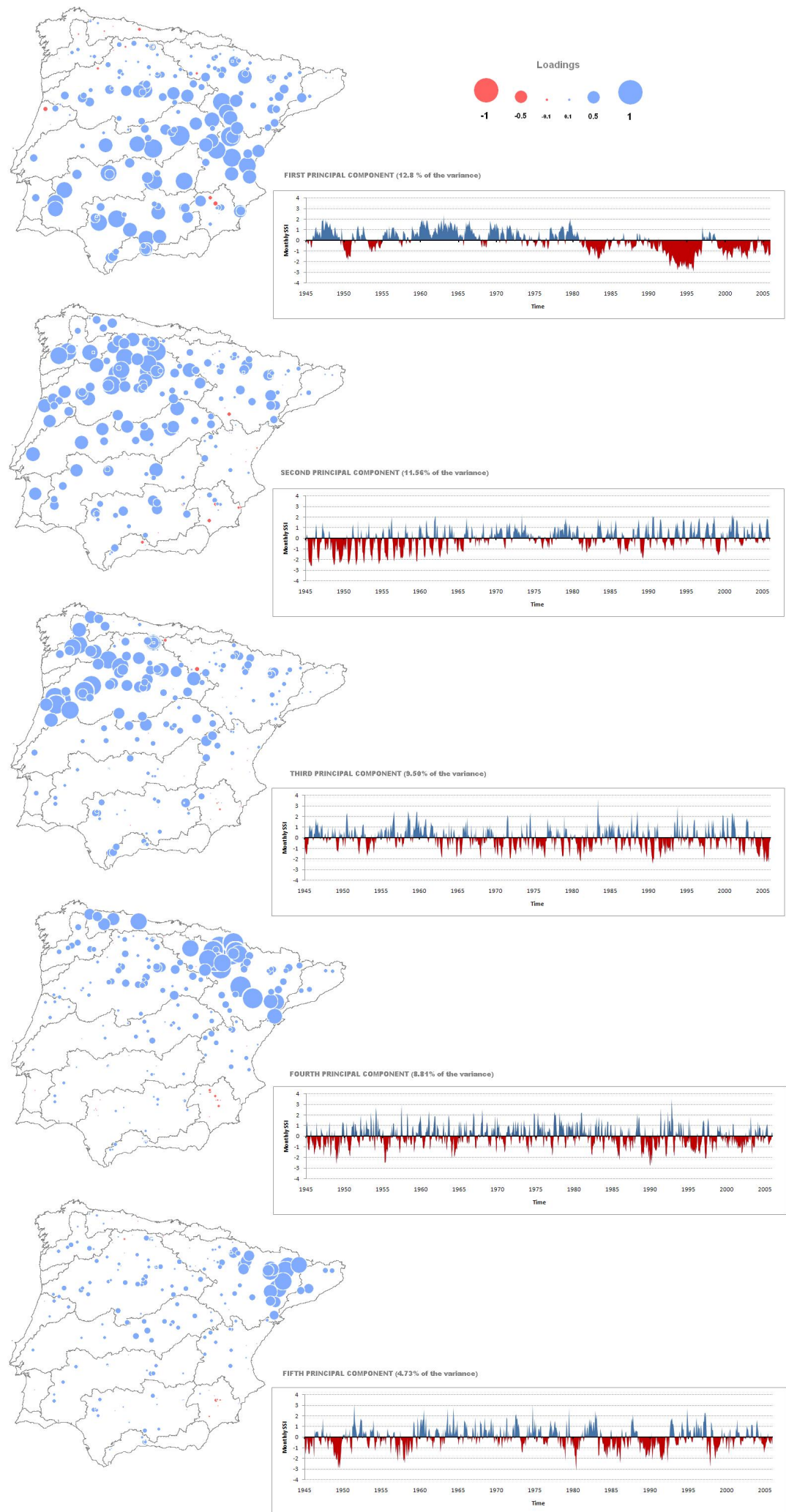

Fig. 4. Spatial distribution of the PCA loadings for the first principal components (1st to 5th), and temporal evolution of the principal components (1st to 5 th). 
the IP, moderately high for the right bank tributaries of the Guadalquivir River, and strong in the case of the Andalusian basins.

PC7 explained $2.67 \%$ of the variance, and was only representative of the evolution of the SSI in the Mundo River system (Segura basin). The temporal evolution of PC7 showed a low frequency between dry and humid periods, and two contrasting periods were evident. From 1945 to 1978 the droughts were frequent, long lasting and of intermediate intensity, while from 1978 to 2005 the droughts were much less frequent, and moist periods predominated.

PC8 explained $2.15 \%$ of the variance and was represented by the right bank tributaries and the low reaches of the Segura River. Its evolution reflected a low frequency in the succession of dry and humid periods, which were interspersed. The moist period lasting from 1945 to 1955 was followed by a drought period from 1955 to 1973, then by a short moist period (1973-1975), and finally a dry period that lasted until 1990. The period from 1990 to 1995 was moist (substantial discharges occurred), and was followed by another dry period that lasted until 2005.

PC9 also showed a low temporal frequency between dry and moist periods. Drought episodes were common during the study period, but two major drought episodes occurred, from 1965 to 1968 and from 1999 to 2004, and were directly correlated with the Catalonian basins, especially those in the north. PC10 was moderately correlated with the headwaters of the Tajo and Júcar basins, and was associated with a low frequency between dry and moist periods; major multi-year droughts were recorded from 1959 to 1964, and from 1996 to 2005 .

\subsection{Drought characteristics}

Following the methodology shown in Sect. 3.4, we derived the duration and magnitude of each delimited streamflow drought event. In this way, we obtained series of drought duration and magnitude for each PC. Figure 6 shows the cumulative absolute frequencies of drought duration and magnitude for the drought events recorded in each region; these are arranged from shortest to longest in the case of drought duration, and from smallest accumulated deficit to largest accumulated deficit in the case of drought magnitudes. Marked differences were found among regions. With respect to drought characteristics, three main groups were evident. The first, integrated solely by PC1, had few drought episodes, although these were characterized by long duration and high magnitude. The occurrence of 7 hyper-annual drought episodes exceeding one year in duration, and two exceptional droughts exceeding $5 \mathrm{yr}$ in duration, showing that the PC1 hydrological region had the most pronounced droughts over time and consequently registered the greatest accumulated streamflow deficits. The second group in relation to drought duration was integrated by PCs 2,5 and 710. All these had a large number of dry episodes (70-100), with maximum durations of 25-35 months. Drought magnitudes are closely related to the duration of drought episodes, and thus the internal composition of the group regarding the accumulated deficits is almost the same as for duration. The third group of regions in relation to drought events was integrated by PCs 3, 4 and 6 . All of these had more than 100 short drought episodes that never exceeded 20 months in duration, which generated minor SSI deficits and low drought magnitudes.

\subsection{Changes in duration and magnitude}

Table 1 summarizes the drought characteristics (duration and magnitude) of each PC for the periods 1945-1974 and 19752005. For PC1 there was a clear increase in the number of drought events in the second period $(n=27)$ relative to the first $(n=21)$. The drought duration and magnitude also increased considerably in the second period, to an average drought duration of 10 months and an accumulated deficit of 15 SSI units. The maximum duration increased from 15 to 66 months, and the maximum accumulated SSI deficit increased from 16 to 113 SSI units. For PC2 there was a slight increase in the number of drought events from 1975 to 2005, but a decrease occurred in the average and maximum duration and magnitude of the drought episodes. For PCs 3-6 the patterns were very similar, all showing a moderate increase in the average duration and magnitude of drought events in the second half of the study period. However, with the exception of PC5, the maximum drought duration and magnitude increased from 1975 to 2005 . For PC7 there was an increase in the number of drought episodes, although substantial decreases were observed in the average drought duration and magnitude during the second period. For PC8 the pattern was similar in the two periods, although the maximum duration and magnitude increased considerably during the second period. For PC9 there was a slight decrease in the average duration and magnitude of drought episodes, whereas both the maximum duration and magnitude increased. For PC10 the pattern was similar in the two periods, although the maximum duration and magnitude decreased somewhat.

\subsection{Drought spatial coverage}

Figure 7 shows the temporal evolution of the percentage of area affected by drought (SSI $<-0.84)$ and severe drought (SSI $<-1.65)$ during the study period. Three main stages are evident in this evolution. The first, during the decades of 1940 and 1950, was a period when the area affected by drought often exceeded $40 \%$ of the IP. In this period approximately $25 \%$ of the analyzed sub-basins were subject to severe drought conditions during the drought episodes in 1945, 1949, 1950 and 1954. The second stage, encompassing the decades of 1960 and 1970, was a period when the area affected by drought was low (approximately $20 \%$ or less). An exception was the occurrence of dry episodes in 1965 and 

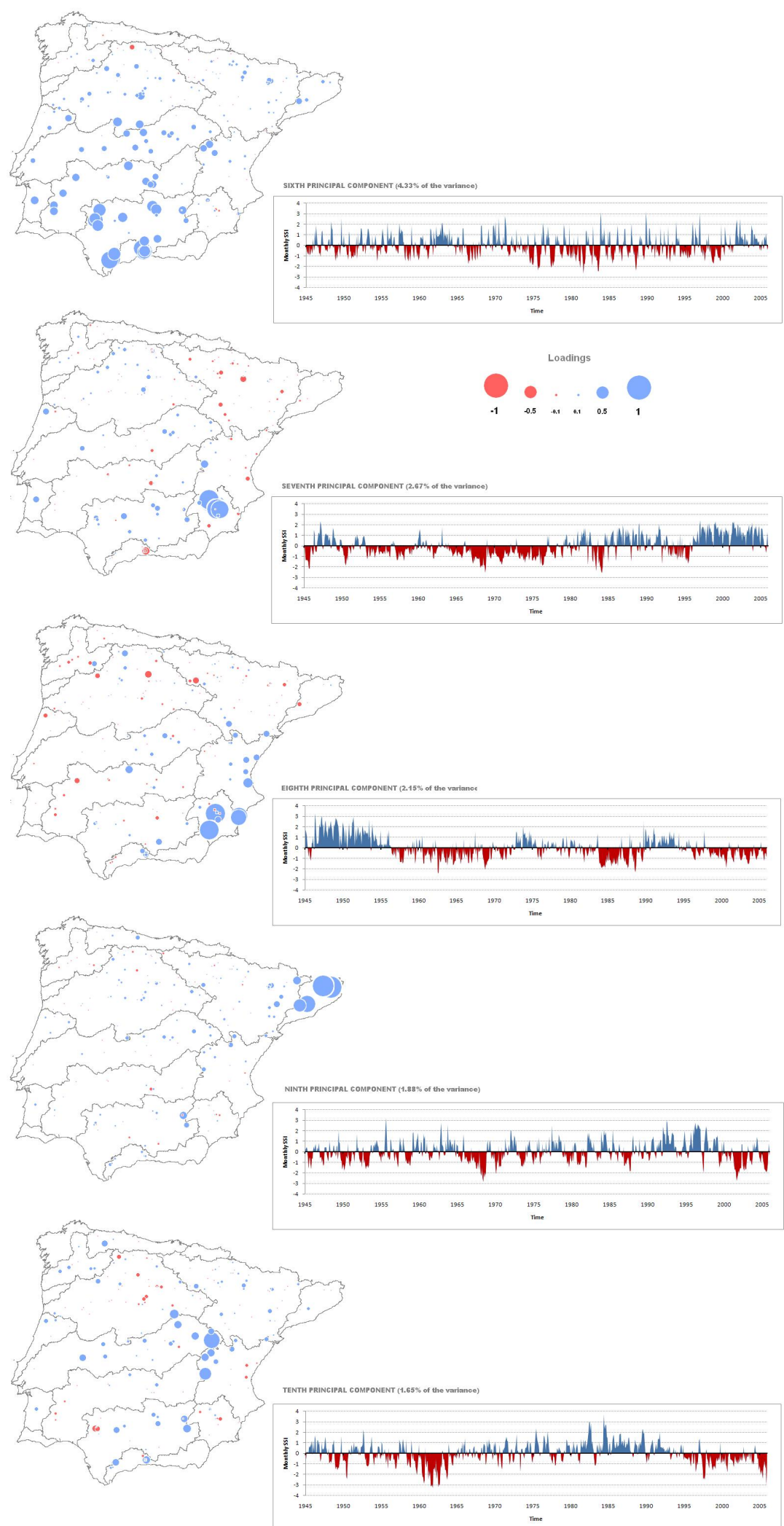

Fig. 5. Spatial distribution of the PCA loadings for the first principal components (6th to 10th), and temporal evolution of the principal components (6th to 10 th). 
Table 1. Streamflow drought duration and accumulated deficits for two contrasted periods (1945-1974 and 1975-2005) for each principal component.

\begin{tabular}{|c|c|c|c|c|c|c|c|c|c|c|c|c|}
\hline & \multicolumn{4}{|c|}{ 1945-1974 } & \multicolumn{4}{|c|}{ 1975-2005 } & \multirow{2}{*}{\multicolumn{4}{|c|}{$\begin{array}{c}\text { Periods comparison } \\
1975-2000 \text { respect to } 1945-1974\end{array}$}} \\
\hline & \multirow{2}{*}{$\begin{array}{r}\text { Mean } \\
\text { duration }\end{array}$} & \multirow{2}{*}{$\begin{array}{r}\text { Max. } \\
\text { duration }\end{array}$} & \multirow{2}{*}{$\begin{array}{r}\text { Mean } \\
\text { Magnitude }\end{array}$} & \multirow{2}{*}{$\begin{array}{r}\text { Max. } \\
\text { Magnitude }\end{array}$} & \multirow{2}{*}{$\begin{array}{r}\text { Mean } \\
\text { duration }\end{array}$} & \multirow{2}{*}{$\begin{array}{r}\text { Max. } \\
\text { duration }\end{array}$} & \multirow{2}{*}{$\begin{array}{r}\text { Mean } \\
\text { Magnitude }\end{array}$} & \multirow{2}{*}{$\begin{array}{r}\text { Max. } \\
\text { Magnitude }\end{array}$} & & & & \\
\hline & & & & & & & & & \multirow{2}{*}{$\begin{array}{l}\text { Mean } \\
\text { duration }\end{array}$} & \multirow{2}{*}{$\begin{array}{l}\text { Max. } \\
\text { duration }\end{array}$} & \multirow{2}{*}{$\begin{array}{l}\text { Mean } \\
\text { Magnitude }\end{array}$} & \multirow{2}{*}{$\begin{array}{l}\text { Max. } \\
\text { Magnitude }\end{array}$} \\
\hline & (mo & ths) & (accumulate & SSI deficit) & $(\mathrm{mo}$ & ths) & (accumulate & SSI deficit) & & & & \\
\hline $\mathrm{PC} 1$ & 3.7 & 15.0 & 2.0 & 16.4 & 9.8 & 66.0 & 9.5 & 113.2 & Increase & Increase & Increase & Increase \\
\hline PC2 & 4.8 & 26.0 & 5.1 & 34.1 & 3.6 & 9.0 & 2.0 & 9.1 & Decrease & Decrease & Decrease & Decrease \\
\hline PC3 & 2.7 & 8.0 & 1.8 & 8.3 & 4.1 & 17.0 & 3.5 & 18.4 & Increase & Increase & Increase & Increase \\
\hline PC4 & 2.9 & 11.0 & 2.2 & 12.3 & 3.3 & 18.0 & 2.6 & 15.5 & Increase & Increase & Increase & Increase \\
\hline PC5 & 3.0 & 19.0 & 2.3 & 27.4 & 4.6 & 21.0 & 3.8 & 23.0 & Increase & Increase & Increase & Decrease \\
\hline PC6 & 2.9 & 10.0 & 1.8 & 8.2 & 4.2 & 18.0 & 3.7 & 17.4 & Increase & Increase & Increase & Increase \\
\hline PC7 & 8.4 & 33.0 & 6.2 & 39.1 & 3.4 & 25.0 & 2.7 & 26.9 & Decrease & Decrease & Decrease & Decrease \\
\hline PC8 & 4.1 & 16.0 & 3.0 & 14.5 & 4.7 & 33.0 & 3.4 & 43.1 & Increase & Increase & Increase & Increase \\
\hline PC9 & 4.7 & 12.0 & 3.7 & 21.0 & 4.1 & 15.0 & 3.1 & 22.9 & Decrease & Increase & Decrease & Increase \\
\hline PC10 & 4.3 & 26.0 & 3.8 & 49.0 & 4.6 & 21.0 & 3.3 & 22.1 & Increase & Decrease & Decrease & Decrease \\
\hline
\end{tabular}
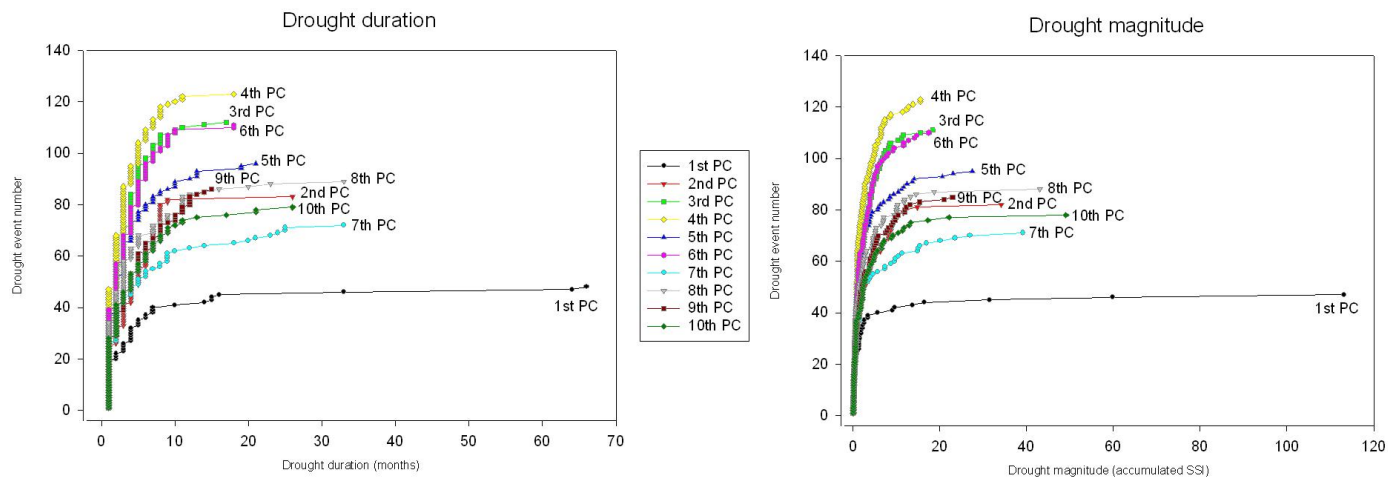

Fig. 6. Left: duration (in months) of the drought episodes (from shortest to longest event). Right: magnitude (in accumulated SSI deficits) of the drought episodes (from minor to major).

1976, when the drought-affected area exceeded $40 \%$ of the study area. The third and longest stage lasted from 1980 to 2005. During this stage the drought-affected area often exceeded $50 \%$ of the study area, and in 1981, 1992, 1993, 1995 and 2000 the peak area affected exceeded $70 \%$. The area affected by severe drought during this stage followed a similar pattern to that of the first stage, although occurrences of the affected area exceeding $30 \%$ were restricted to 1992 , 1993, 1995 and 2000. The shapes of the graphs of drought and severe drought follow a similar pattern because their occurrences were closely related. However, the slopes of the curves showed a stationary behavior in terms of the percentage area affected by severe droughts (SSI $<-1.65)$, whereas the percentage area affected by droughts (SSI $<-0.84)$ increased from 1945 to 2005 , particularly in the later years.

The analysis above shows the great spatial complexity of droughts in the IP. Thus, individual drought episodes can have very different spatial patterns in terms of onset, intensity, spatial propagation and area affected. Figures 8 and 9 illustrate this complexity through examples showing very different spatiotemporal evolutions of two drought episodes in the IP. Figure 8 shows the spatial coverage of the sub-basins affected by drought and severe drought during

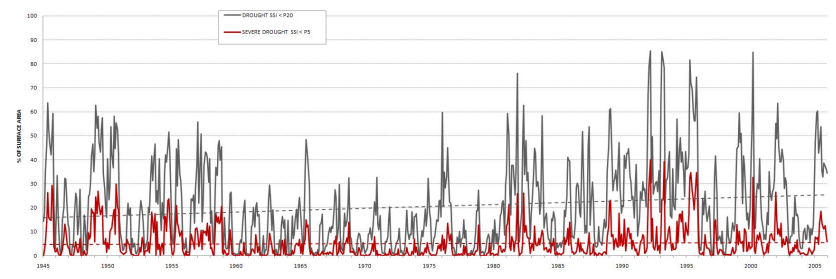

Fig. 7. Temporal evolution of the percentage of affected area by streamflow droughts. The grey line depicts discharges under -0.84 of the standardized streamflow series. The red line depicts discharges under -1.65 .

the dry episode of 1948-1949. The genesis of this streamflow drought was in April 1948, in the northern sector of the IP and the headwaters of the Guadalquivir basin. Two months later, severe drought conditions were established in the headwaters of the Ebro and Guadalquivir basins. In August 1948, dry conditions had spread to most parts of the Ebro and Júcar basins, and to specific catchments of the Duero, Tajo and Guadiana basins. In the following months (from October 1948 to April 1949) the development of this drought event was characterized by the establishment of 


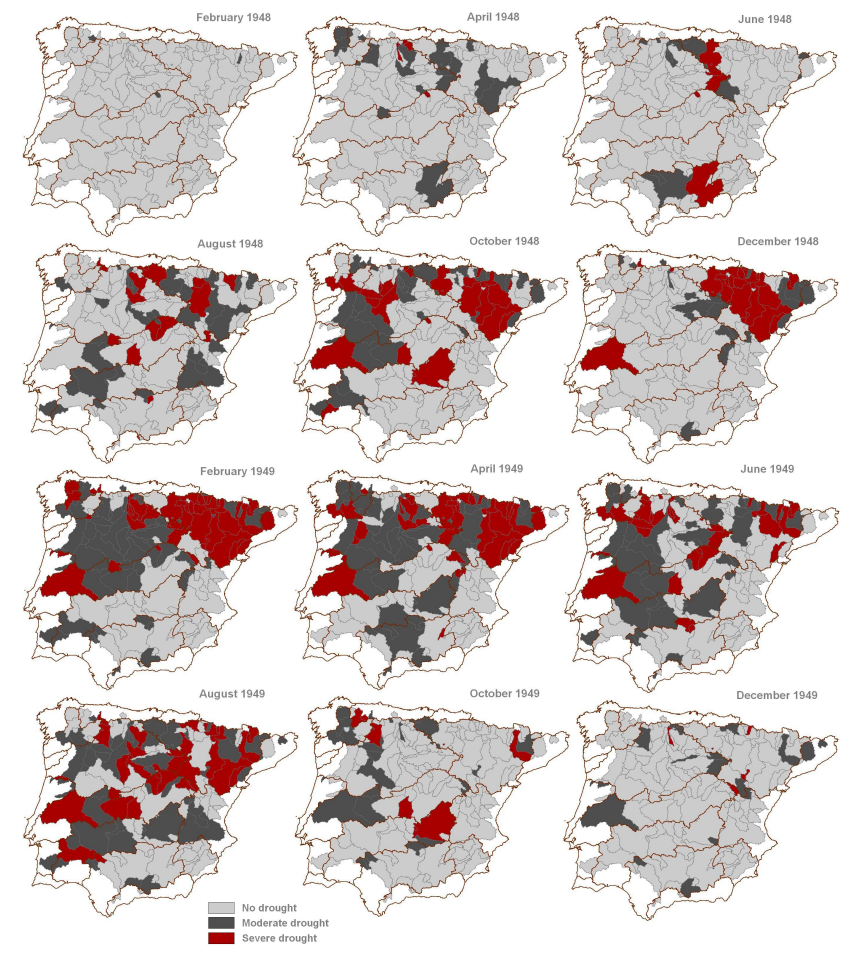

Fig. 8. Spatial coverage of the affected areas during the 1948-1949 drought. Dark grey depicted moderate drought conditions and red depicted severe drought conditions.

severe drought conditions throughout most of the Ebro basin. This transboundary drought extended throughout the western sector of the IP, seriously affecting the Duero, Tajo and Guadiana basins between February 1949 and June 1949. After reaching a second peak of maximum extent during August 1949, the drought weakened in the autumn of 1949 and had almost disappeared by December 1949. Figure 9 shows the spatial propagation of the drought episode that affected the IP in 1992 and 1993. The core area of this drought episode was the middle and lower reaches of the southernmost basins (Guadiana, Guadalquivir and Júcar) of the IP. Its genesis was in the autumn of 1991, and the area affected by water shortages rapidly expanded northwards, encompassing the middle reaches of the Duero, Tajo and Ebro basins by December 1991. Severe drought conditions had established over much of the major northern basins (Miño, Duero and Ebro) by February 1992. A decline in the area affected by drought occurred in the following months, although drought conditions were present in several sub-basins during summer 1992, especially those in the Júcar basin. The spatial extent of the drought expanded in December 1992, and was concentrated mainly in the southern basins. A second peak of maximum drought coverage occurred in late winter and early spring 1993, when more than $80 \%$ of sub-basins were under drought conditions. After April 1993 the drought weakened in the northern sector of the IP, and progressively disappeared

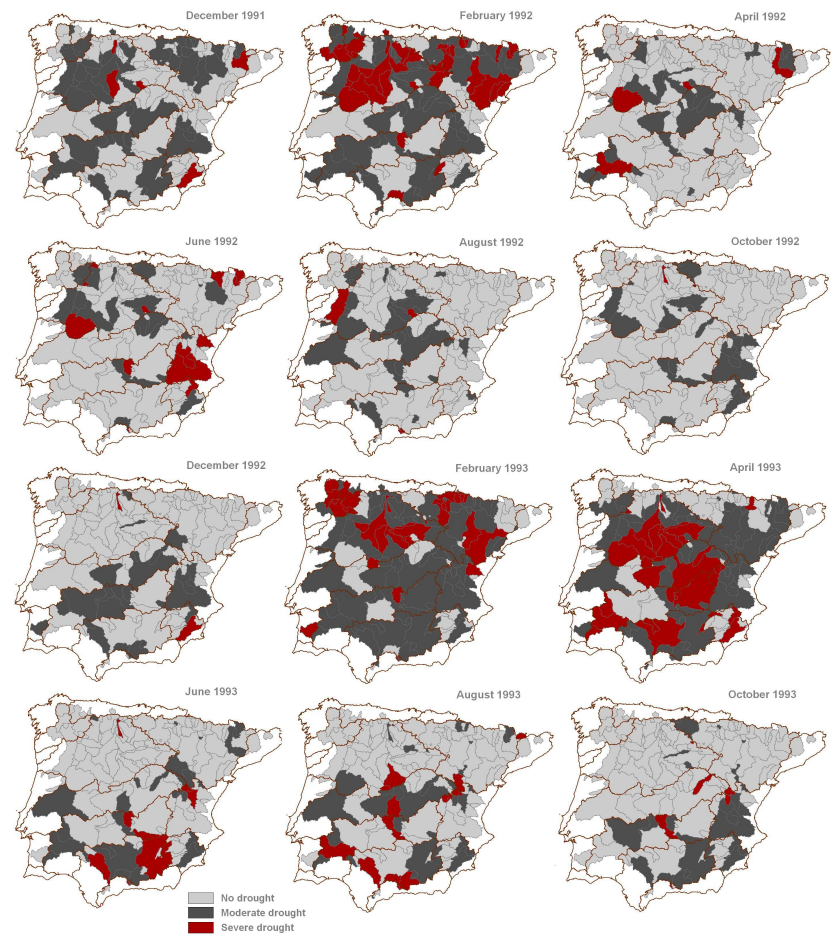

Fig. 9. Spatial coverage of the affected areas during the 1992-1993 drought. Dark grey depicted moderate drought conditions and red depicted severe drought conditions.

during summer and autumn 1993. Both of these examples highlight the complexity of hydrological droughts and the very different spatiotemporal patterns of the phenomenon in the IP.

\section{Discussion}

A recent trend towards the development of different approaches to assess streamflow droughts is emerging, encompassing the study of perturbed and regulated river basins, which correspond to most of the large basins both in developing and developed countries. For example, Timilsena et al. (2007) evaluated drought scenarios of the Colorado River basin (USA), including perturbed hydrological subbasins. Wu et al. (2008) followed a similar approach, using a threshold level approach and the theory of runs to analyze streamflow droughts in the Missouri River basin in Nebrasaka (USA), despite the numerous dams and reservoirs built for irrigation and other uses within the basin. Wen et al. (2011) also assessed the impacts of regulation and water diversion on the nature of hydrological droughts in the Murrumbidgee River (Australia). Thus, including regulated rivers in the evaluation of hydrological droughts should be a compulsory task since regulation and water management may be reinforcing streamflow droughts downstream the dams. This has been shown in different basins of the Iberian Peninsula. 
For example, López-Moreno et al. (2009) assessed the effects of a large transboundary dam between Spain and Portugal on hydrological droughts in the Tagus basin (Iberian Peninsula; IP), showing how the nature of droughts had experienced severe changes downstream of the Alcántara Dam. These changes are associated with an increase in both the duration and the magnitude of drought episodes as a consequence of the dam management, with implications for the availability of water resources downstream affecting the Portuguese part of the basin. In the headwaters of the Tagus basin, Lorenzo-Lacruz et al. (2010) also showed how dam operation for irrigation purposes and water transfer has altered the natural regime of the river and increased the duration and magnitude of low flows downstream, with implications on the water availability and quality in the medium course of the river. This has been a great source of conflicts between ecologists, agrarian organizations of the basin and the water managers. Thus, independently of the origin of the streamflow droughts (climatic or driven by the water management), they cause negative impacts and stress the need of analyzing in depth the impacts of water management on hydrological droughts. The results of the studies cited above are even more interesting than those focused on "natural" basins since operational water management recommendations may be derived for the results. All the mentioned studies indicated that water management associated with the exploitation of reservoirs is responsible for the temporal aggregation and aggravation of hydrological droughts downstream the dams.

The objectives of our study were focused on the characterization of hydrological droughts in the IP, independently of the regulation level of the rivers, with the scope limited to the assessment of the changes observed in the duration and magnitude of the streamflow droughts. However, since the reality is that Iberian rivers are mostly regulated and affected by diverse human activities, the inclusion of regulated systems is necessary to encompass the variability and the impacts induced by dams on the changes in the streamflow droughts. Thus, the analysis allows the definition of independent hydrological regions with distinctive drought characteristics (it is noteworthy that the most severe and lasting droughts were observed in those basins with a high degree of regulation).

Our analysis was based on a hydrological regionalization, using principal component analysis applied to 187 series of the SSI (Vicente-Serrano et al., 2011) distributed homogenously across the entire IP. We used an alternative approach to define homogeneous hydrological regions for the specific analysis of their responses to droughts, since the most extended methodology used with this purpose is based on cluster analysis (Stahl and Demuth, 1999; Fleig et al., 2011). The use of a streamflow drought index (the SSI) enabled us to perform a PCA using standardized variables, comparable in time and space, and thus identify regions with homogeneous streamflow (high and low) characteristics. The efficacy of this method has been proved in several regions worldwide (Johnston and Shmagin, 2008; Kahya et al., 2008;
Peterson et al., 2011). The PCA performed quite well in our case, as the regionalization obtained showed highly coherent geographical patterns with well-defined natural boundaries (mainly mountain ranges). The Iberian Plateau is divided in two by the Central System, which also originates a separation between PC 1 and 2. The Cantabrian and the Iberian Ranges separate the Plateau unit (PC1 and PC2) from the Ebro Valley (PC4). A different coastal influence in the Pyrenees creates a distinction between the western Pyrenean basins (Atlantic Sea influence; PC4), the central basins (with the highest altitudes; PC5) and the Catalonian basins (opened to the Mediterranean Sea influence; PC9). Nevertheless, the spatial variability of streamflow droughts in the IP is greater than the observed variability of climatic droughts; the latter was summarized in just 6 PCs (Vicente-Serrano, 2006a, b). However, the first 10 PCs only explained $60 \%$ of the total variance. This highlights the great complexity and number of factors that generate the water yield in a basin (Krasovskaia et al., 1994; Fleig et al., 2011). Besides climate variability and the physiographic complexity of the different basins, the water management model established in the IP, which is based on the concept of "basin unity", generates greater differences between the behavior of basins belonging to one basin water agency vs. to another (e.g. Confederación Hidrográfica del Ebro versus Confederación Hidrográfica del Duero). The different water management strategies implemented among agencies increase the complexity of the regionalization. Moreover, at the local scale the perturbations caused by pumping and extraction introduce even more complexity.

The general patterns reported here for the evolution and occurrence of streamflow droughts in the IP (with the driest decades being the 1950s, 1980s, 1990s and 2000s) are consistent with findings related to climatic droughts reported by Briffa et al. (1994), Maheras (1988) and VicenteSerrano (2006a) for Europe, the Mediterranean region, and the IP, respectively. Our findings are also consistent with an analysis by Hannaford et al. (2011) of streamflow droughts that partially included the IP. These results also showed a high degree of consistency with the results presented in Lorenzo-Lacruz et al. (2012), where Iberian streamflow trends analysis was addressed using this same dataset.

In addition to the general patterns, the 10 hydrological regions delimited with respect to streamflow behaviour have very different climatic, water regulatory and physiographic characteristics that have caused or conditioned the various streamflow drought typologies. The hydrological behavior of the region correlated with PC1, which was characterized by severe and persistent droughts, can be explained by various factors. The precipitation in this region is strongly associated with the North Atlantic Oscillation, which has been demonstrated to have a marked influence on the variability of streamflows during winter and spring (López-Moreno et al., 2007; Lorenzo-Lacruz et al., 2011). The permeable lithology of the region, which results in slow groundwater 
recharge, and the multi-year regulation of dams within the basins concerned can cause temporal delays in the occurrence of streamflow deficits with respect to the lack of precipitation (Lorenzo-Lacruz et al., 2010). The relationship between PC1 and precipitation in the southern parts of the Iberian Range (located near the headwaters of the Tajo, Júcar and Guadiana rivers) exemplifies the delays noted above. We found a maximum correlation $(R=0.76)$ between the standardized precipitation index (SPI) for this area and PC1 at a 25-month time scale, demonstrating the multi-year dependence of streamflows on climatic conditions that cause longlasting droughts in this hydrological region, which was also observed in Lorenzo-Lacruz et al. (2010). Moreover, the orographic node that represents the southern Iberian Range is a critical zone for water management within the IP. This is because the southern Iberian Range acts to divert water between the Ebro, Tajo and Júcar basin headwaters, conditions the streamflow response to droughts in the middle and lower reaches of the basins correlated with PC1 (12.8\% of the explained variance and $40.8 \%$ of the study area), and determines the quantity of water that can be transferred to the Segura basin. Of additional significance is the water demand of the coastal zone of the Júcar basin, where the marked seasonal pattern in occupancy because of tourism exacerbates drought events during summer (Collins et al., 2009). The drought characteristics of the hydrological region defined by PC2 may be related to the Atlantic Ocean influence, which is the main source of humid air masses responsible for precipitation in this region, and the high altitudes, which determine the snow and rainfall regimes characteristic of the headwaters of this region (Morán-Tejeda et al., 2011). The trend towards fewer intra-annual drought events in this region (mainly the Duero basin) is closely related to the water regulation strategy, which increases river discharges during summer (avoiding the worse seasonal droughts during the dry season) at the expense of reducing streamflows during winter and spring. The PC 3 basins interspersed with the PC2 hydrological region have a very low level of regulation; consequently, the climatic signal might be of great importance in defining streamflow behavior. It is noteworthy that a significant negative correlation $(R=-0.35, \alpha<0.01)$ was evident between PC3 in winter and the winter NAO index. The hydrological region defined by PC4 is bounded by the orography of the Cantabrian, Pyrenean and Iberian ranges, which channel the northern humid air masses towards the Ebro Valley. Thus, northern flows from the Cantabrian Sea feed the Cantabrian basins, the Atlantic Pyrenean basins and the Ebro headwaters. The latter two are the major contributors to streamflow in the main course of the Ebro River (Batalla et al., 2004), and consequently determine the conditions in the upper reaches of the Ebro basin (which are regulated by the Ebro reservoir in the headwaters) and control drought occurrence downstream in the lower reaches. According to Martín-Vide and López-Bustins (2006), the positive phase of the Western Mediterranean Oscillation (WeMO) determines rainfall in the zones adjacent to the Gulf of Biscay, which is reflected in the streamflow behavior of the hydrological region defined by PC4, and accounts for the significant positive correlation between PC4 in winter and the winter WeMO index $(R=0.52)$. The drought-related region associated with PC5 is characterized by mountainous rivers, which are related to the high altitude and steep slopes. In this area snowmelt plays an important hydrological role and causes a significant delay in the SSI response to climatic conditions (between 2 and 10 months, depending on the level of regulation) (Vicente-Serrano and López-Moreno, 2005). The streamflow drought characteristics of the PC6 hydrological region may be related to the small area involved and the low altitude of the catchments. These factors result in frequent but short drought episodes because of the ephemeral regime of the streams, which usually have moderate or high streamflows during the wet season but are dry during the remainder of the year (Liquete et al., 2005). The reduction in drought episodes in the hydrological region represented by PC7 reflects the dependence of this area on water transferred from the headwaters of the Tagus River. Since 1979 the Tajo-Segura water transfer has transferred an average of $331 \mathrm{hm}^{3}$ of water per year for irrigation purposes, and for urban supply to a population of 2.5 million (Rico-Amorós, 2004). This dependence is evident in the highly significant correlation $(R=0.65, \alpha<0.01)$ between PC7 and the standardized streamflow series for the water transfer. However, a clear relationship between PC7 and PC8 was found. Since the water transfer began, aquifer overexploitation for irrigation and leisure purposes has occurred in the Segura basin, including many sub-basins belonging to the PC8 hydrological region, leading to depletion of the aquifers (Custodio, 2002) and an increase in the number of drought episodes. No clear causalities were found to explain the different drought typologies observed for the PC9 and PC10 hydrological regions.

In general, drought duration is negatively correlated with the number of drought events. Nevertheless, a worsening situation with respect to drought duration in the IP has been developing since the 1970s, with many sub-basins having been subject to longer and more severe droughts in recent years. The results suggest that rainfall following droughts has typically been unable to generate the surpluses needed to restore the hydrological conditions that were present prior to the drought. This could be related to increasing consumption of water as a consequence of the rapid development of irrigated agriculture and the demands of tourism (Lorenzo-Lacruz et al., 2010). In unregulated basins, increasing drought duration and magnitude are affecting the maintenance of ecological flows and threatening the maintenance of riparian and river associated ecosystems. The absence of reservoirs to smooth the impacts of drought on naturalized streamflows increases the vulnerability of these basins to the occurrence of droughts. 
Two contrasting patterns in the temporal evolution of the spatial extent of drought-affected areas were observed. For moderate droughts there was a trend toward increase in the spatial extent, which may be related to the observed trend toward decreasing precipitation during specific months (Xoplaki et al., 2004; Mourato et al., 2010; González-Hidalgo et al., 2011), water management processes, and increasing use of water for activities including irrigation and urban supply (Rico-Amorós, 2004). In contrast, the size and number of areas affected by severe droughts (under 5th percentile) has remained relatively stable during the last $60 \mathrm{yr}$. Expansion of these areas has been moderated by water regulation strategies to provide ecological flows that maintain riparian ecosystems, at the expense of suffering alterations to their composition and structure (Boix et al., 2010).

The heterogeneity observed in the genesis and spatial propagation of droughts over time confirms the view that no two droughts are identical, and that droughts are not static (Wilhite, 2005). We observed that the core area of a drought can shift, and its spatial extent can expand and contract until its disappearance. Consequently, the monitoring and assessment of drought episodes is of great relevance to the development of early warning systems and management strategies to mitigate the impacts of droughts.

\section{Conclusions}

This study provides a comprehensive analysis of the spatiotemporal characteristics of streamflow droughts in the Iberian Peninsula during the second half of the 20th century. It represents a novel contribution since we used an extensive spatiotemporal dataset that had not previously been used for this purpose or spatial context. The dataset may be a useful aid for water managers and politicians, and the methods used were based on standard procedures applied in recent years to the characterization of streamflow droughts.

The PCA performed well, and revealed quite consistent spatial patterns related to the regionalization. The methodology was capable of pinpointing and delimiting drought episodes and the characteristics associated with them. This approach enabled us to define various drought typologies having contrasting durations and magnitudes. The results show that in terms of drought duration and magnitude the situation is becoming worse in the majority of the hydrological regions delimited by the PCA. The area affected by droughts is also increasing, which may threaten the maintenance of current water supplies and consumptive water uses in the IP. We also found substantial spatial heterogeneity in the genesis, evolution and disappearance of streamflow droughts, highlighting the great complexity of this phenomenon. This complexity is exacerbated in the IP by the highly variable climate, the complex orography, the extensive water regulation systems, and the contrasting water demands among regions.
Acknowledgements. We would like to thank the Centro de Estudios Hidrográficos (CEDEX), Sistema Nacional de Informaçâo de Recursos Hídricos (SNIRH), Agència Catalana de l'Aigua, Agencia Andaluza del Agua and Augas de Galicia for providing the hydrological data used in this study. This work has been supported by a pre-doctoral fellowship by the Aragón Government (Spain), and by the research projects CGL2006-11619/HID, CGL200801189/BTE, CGL2011-27574-C02-02 and CGL2011-27536 financed by the Spanish Commission of Science and Technology and FEDER, EUROGEOSS (FP7-ENV-2008-1-226487) and ACQWA (FP7-ENV-2007-1-212250) financed by the VII Framework Programme of the European Commission, and "La nieve en el Pirineo Aragonés y su respuesta a la variabilidad climática" and "Efecto de los escenarios de cambio climático sobre la hidrología superficial y la gestión de embalses del Pirineo Aragonés" financed by "Obra Social La Caixa" and the Aragón Government.

Edited by: D. Mazvimavi

\section{References}

Abramowitz, M. and Stegun, I. A.: Handbook of mathematical functions, Dover Publications, New York, 1965.

Albiac, J., Uche, J., Valero, A., Serra, L., Meyer, A., and Tapia, J.: The economic unsustainability of the Spanish National Hydrological Plan, Int. J. Water Resour. D., 19, 437-458, 2003.

Arroyo-Ilera, F.: Territorio, tecnología y capital, La regulación hidroeléctrica de los ríos españoles [1900-1970], Treballs de la Societat Catalana de Geografía, 63, 39-70, 2007.

Berga-Casafont, L.: Presas y embalses en la España del siglo XX, Revista de Obras Públicas, 3438, 37-40, 2003.

Batalla, R. J., Gómez, C. M., and Kondolf, G. M.: Reservoirinduced hydrological changes in the Ebro River basin [NE Spain], J. Hydrol., 290, 117-136, 2004.

Boix, D., García-Berthou, E., Gascón, S., Benejam, L., Tornés, E., Sala, J., Benito, J., Munné, A., Solá, C., and Sabater, S.: Response of community structure to sustained drought in Mediterranean rivers, J. Hydrol., 383, 135-146, 2010.

Briffa, K. R., Jones, P. D., and Hulme, M.: Summer moisture variability across Europe, 1892-1991: an analysis based on the Palmer drought severity index, Int. J. Climatol., 14, 475-506, 1994.

Collins, R., Kristensen, P., and Thyssen, N.: Water resources across Europe - confronting water scarcity and drought, European Environmental Agency, 2009.

COPA-COGECA: Assessment of the impact of the heat wave and drought of summer 2003 in agriculture and forestry, Committee of Agricultural Organizations in the European Union, 2003.

Custodio, E.: Aquifer overexploitation: what does it mean?, Hydrogeol. J., 10, 254-277, 2002.

De-Castro, M., Martín-Vide, J., and Alonso, S.: El clima de España: pasado, presente y escenarios de clima para el siglo XXI, Impactos del cambio climático en España, Ministerio Medio Ambiente: Madrid, 2005.

Dracup, J. A., Lee, K. S., Paulson Jr., E. G.: On the statistical characteristics of drought events, Water Resour. Res., 16, 289-296, 1980.

EEA: Sustainable Water Use in Europe, Part 3. Extreme hydrological events: Floods and droughts, 2001. 
Fleig, A. K., Tallaksen, L. M., Hisdal, H., and Demuth, S.: A global evaluation of streamflow drought characteristics, Hydrol. Earth Syst. Sci., 10, 535-552, doi:10.5194/hess-10-535-2006, 2006.

Fleig, A. K., Tallaksen, L. M., Hisdal, H., and Hannah, D. M.: Regional hydrological drought in north-western Europe: linking a new Regional Drought Area Index with weather types, Hydrol. Process., 25, 1163-1179, 2011.

Gámiz-Fortis, S. R., Esteban-Parra, M. J., Trigo, R. M., and CastroDíez, Y.: Potential predictability of an Iberian river flow based on its relationship with previous winter global SST, J. Hydrol., 385, 143-149, 2010.

González-Hidalgo, J. C., Brunetti, M., and De-Luis, M.: A new tool for monthly precipitation analysis in Spain: MOPREDAS database [monthly precipitation trends December 1945-November 2005], Int. J. Climatol., 31, 715-731, 2011.

Gudmundsson, L., Tallaksen, L. M., Stahl, K., and Fleig, A. K.: Low-frequency variability of European runoff, Hydrol. Earth Syst. Sci., 15, 2853-2869, doi:10.5194/hess-15-28532011, 2011.

Hannaford, J., Lloyd-Hughes, B., Keef, C., Parry, S., and Prudhomme, C.: Examining the large-scale spatial coherence of European drought using regional indicators of precipitation and streamflow deficit, Hydrol. Process., 25, 1146-1162, 2011.

Hisdal, H., Stahl, K., Tallaksen, L. M., and Demuth, S.: Have streamflow droughts in Europe become more severe or frequent?, Int. J. Climatol., 21, 317-333, 2001.

Hisdal, H., Tallaksen, L. M., Clausen, B., Peters, E., and Gustard, A.: Hydrological drought characteristics, in: Hydrological Drougth - Processes and estimation methods for streamflow and groundwater, edited by: Tallaksen, L. M. and van Lanen, H. A. J., Developments in Water Science, Elsevier Science, 48, 139-198, 2004.

Iglesias, A., Garrote, L., Flores, F., and Moneo, M.: Challenges to manage the risk of water scarcity and climate change in the Mediterranean, Water Resour. Manage., 21, 775-788, 2007.

Johnston, C. A. and Shmagin, B. A.: Regionalization, seasonality, and trends of streamflow in the US Great Lakes Basin, J. Hydrol., 362, 69-88, 2008.

Jollife, I. T.: Principal component analysis: a beginner's guide. Part I: Introduction and application, Weather, 45, 375-382, 1990.

Kahya, E., Kalayci, S., Piechota, T. C.: Streamflow regionalization: case study of Turkey, J. Hydrol. Eng., 13, 205-214, 2008.

Kalayci, S. and Kahya, E.: Assessment of streamflow variability modes in Turkey: 1964-1994, J. Hydrol., 324, 163-177, 2006.

Krasovskaia, I., Arnell, N. W., and Gottschalk, L.: Flow regimes in northern and western Europe: development and application of procedures for classifying flow regimes, in: Flow Regimes from International Experimental and Network Data (FRIEND), IAHSAISH P., 221, 185-192, 1994.

Liquete, C., Arnau, P., Canals, M., and Colas, S.: Mediterranean river systems of Andalusia, southern Spain, and associated deltas: A source to sink approach, Mar. Geol., 222-223, 471495, 2005.

López-Bustins, J. A., Martín-Vide, J., and Sánchez-Lorenzo, A.: Iberia Winter rainfall trends based upon changes in teleconnection and circulation patterns, Global Planet. Change, 63, 171176, 2008.

López-Moreno, J. I., Beguería, S., Vicente-Serrano, S. M., and García-Ruiz, J. M.: Influence of the North Atlantic Oscillation on water resources in central Iberia: Precipitation, streamflow anomalies, and reservoir management strategies, Water Resour. Res., 43, W09411, doi:10.1029/2007WR005864, 2007.

López-Moreno, J. I., Vicente-Serrano, S. M., Beguería, S., GarcíaRuiz, J. M., Portela, M. M., and Almeida, A. B.: Dam effects on droughts magnitude and duration in a transboundary basin: The Lower River Tagus, Spain and Portugal, Water Resour. Res., 45, W02405, doi:10.1029/2008WR007198, 2009.

López-Moreno, J. I., Vicente-Serrano, S. M., Zabalza, J., Beguería, S., Lorenzo-Lacruz, J., Azorin-Molina, C., and Morán-Tejeda, E.: Hydrological response to climate variability at different time scales: A study in the Ebro basin, J. Hydrol., 477, 175-188, 2013.

Lorenzo-Lacruz, J., Vicente-Serrano, S. M., López-Moreno, J. I., Beguería, S., Cuadrat, J. M., and García-Ruiz, J. M.: The impact of droughts and water management in various hydrological systems in the headwaters of the Tagus basin [central Spain], J. Hydrol., 386, 13-26, 2010.

Lorenzo-Lacruz, J., Vicente-Serrano, S. M., López-Moreno, J. I., González-Hidalgo, J. C., and Morán-Tejeda, E.: The response of Iberian rivers to the North Atlantic Oscillation, Hydrol. Earth Syst. Sci., 15, 2581-2597, doi:10.5194/hess-15-25812011, 2011.

Lorenzo-Lacruz, J., Vicente-Serrano, S. M., López-Moreno, J. I., Morán-Tejeda, E., and Zabalza, J.: Recent trends in Iberian streamflows (1945-2005), J. Hydrol., 414, 462-475, 2012.

Maheras, P.: Changes in precipitation conditions in the Western Mediterranean over the last century, J. Climatol., 8, 179-189, 1988.

Martín-Vide, J., and López-Bustins, J. A.: The Western Mediterranean Oscillation and rainfall in the Iberian Peninsula, Int. J. Climatol., 26, 1455-1475, 2006.

McKee, T. B. N., Doesken, J., and Kleist, J.: The relationship of drought frecuency and duration to time scales, in: Eight Conference on Applied Climatology, American Meteorological Society, Anaheim, CA, 179-184, 1993.

Mishra, A. K. and Singh, V. P.: A review of drought concepts, J. Hydrol., 391, 202-216, 2010.

Morán-Tejeda, E., López-Moreno, J. I., Ceballos-Barbancho, A., and Vicente-Serrano, S.: River regimes and recent hydrological changes in the Duero basin [Spain], J. Hydrol., 404, 241-258, 2011.

Mourato, S., Moreira, M., and Corte-Real, J.: Interannual variability of precipitation distribution patterns in Southern Portugal, Int. J. Climatol., 30, 1784-1794, 2010.

Mudelsee, M.: Long memory of rivers from spatial aggregation, Water Resour. Res., 43, W01202, doi:10.1029/2006WR005721, 2007.

Nabaltis, I. and Tsakiris, G.: Assessment of hydrological drought revisited, Water Resour. Manage., 23, 881-897, 2009.

Obasi, G. O. P.: WMO's role in the International Decade for natural disaster reduction, B. Am. Meteorol. Soc., 75, 1655-1661, 1994.

Pandey, R. P., Mishra, S. K., Singh, R., and Ramasastri, K. S.: Streamflow Drought Severity Analysis of Betwa River System (India), Water Resour. Manage., 22, 1127-1141, 2008.

Peterson, H. M., Nieber, J. L., and Kanivetsky, R.: Hydrologic regionalization to assess anthropogenic changes, J. Hydrol., 408, 212-225, 2011.

Post, D. A. and Jakeman, A. J.: Relationships between catchment attributes and hydrological response characteristics in small Aus- 
tralian mountain ash cacthments, Hydrol. Process., 10, 877-892, 1996.

Preisendorfer, R. W.: Principal Component Analysis in Meteorology and Oceanography, Elsevier, New York, 425 pp., 1988.

Quiroga, S., Garrote, L., Iglesias, A., Fernández-Haddad, Z., Schlickenrieder, J., de Lama, B., Mosso, C., and Sánchez-Arcilla, A.: The economic value of drought information for water management under climate change: a case study in the Ebro basin, Nat. Hazards Earth Syst. Sci., 11, 643-657, doi:10.5194/nhess11-643-2011, 2011.

Rico-Amorós, A. M.: Sequías y abastecimiento de agua potable en España, B. Asoc. Geogr. Esp., 37, 137-181, 2004.

Shukla, S. and Wood, A.: Use of a standardized runoff index for characterizing hydrologic drought, Geophys. Res. Lett., 35, L02405, doi:10.1029/2007GL032487, 2008.

Stahl, K.: Hydrological drought, A study across Europe, Phd thesis, Freiburg University, 2001.

Stahl, K. and Demuth, S.: Linking streamflow drought to the occurrence of atmospheric circulation patterns, Hydrolog. Sci. J., 44, 467-482, 1999.

Tallaksen, L. M., Madsen, H., and Clausen, B.: On the definition and modelling of streamflow drought duration and deficit volumen, Hydrolog. Sci. J., 43, 15-33, 1997.

Tallaksen, L. M., Hisdal, H., and Van Lanen, H. A. J.: Space-time modelling of catchment scale drought characteristics, J. Hydrol., 375, 363-372, 2009.

Timilsena, J., Piechota, T. C., Hidalgo, H., and Tootle, G.: Five hundred years of hydrological drought in the upper Colorado river basin, J. Am. Water Resour. As., 47, 798-812, 2007.

UN Secretariat General: United Nations Convention to Combat Drought and Desertification in Countries Experiencing Serious Droughts and/or Desertification, Particularly in Africa, Paris, 1994.

van Loon, A. F., van Lanen, H. A. J., Hisdal, H., Tallaksen, L. M., Fendeková, M., Oosterwijk, J., Horvát, O., and Machlica, A.: Understanding hydrological winter drought in Europe, IAHS Publ., 340, Wallingford, UK, 2010.

Vicente-Serrano, S. M.: Spatial and temporal analysis of droughts in the Iberian Peninsula [1910-2000], Hydrolog. Sci. J., 51, 83-97, 2006a.
Vicente-Serrano, S. M.: Differences in spatial patterns of drought on different time scales: An analysis of the Iberian Peninsula, Water Resour. Manage., 20, 37-60, 2006b.

Vicente-Serrano, S. M. and López-Moreno, J. I.: Hydrological response to different time scales of climatological drought: an evaluation of the Standardized Precipitation Index in a mountainous Mediterranean basin, Hydrol. Earth Syst. Sci., 9, 523-533, doi:10.5194/hess-9-523-2005, 2005.

Vicente-Serrano, S. M., López-Moreno, J. I., Beguería, S., LorenzoLacruz, J., Azorin-Molina, C., and Morán-Tejeda, E.: Accurate computation of a Streamflow Drought Index, J. Hydrol. Eng., 17, 318-332, doi:10.1061/(ASCE)HE.1943-5584.0000433, 2011.

Wen, L., Rogers, K., Ling, J., Saintilan, N.: The impact of river regulation and water diversion on the hydrological drought characteristics in the Lower Murrumbidgee River, Australia, J. Hydrol., 405, 382-391, 2011.

White, D., Richman, H., and Yarnal, B.: Climate regionalization and rotation of principal components, Int. J. Climatol., 11, 1-25, 1991.

Wilhite, D. A.: Drought and water crises, Science, technology, and management issues, Taylor and Francis, 406 pp., 2005.

Wilhite, D. A. and Glantz, M. H.: Understanding the drought phenomenon: the role of definitions, Water Int., 10, 111-120, 1985.

Wilhite, D. A., Svoboda, M. D., and Hayes, M. J.: Understanding the complex impacts of drought: A key to enhancing drought mitigation and preparedness, Water Resour. Manage., 21, 763-774, 2007.

Wu, H., Soh, L.-K., Samal, A., and Chen, X.-H.: Trend analysis of streamflow drought events in Nebraska, Water Resour. Manage., 22, 145-164, 2008.

Xoplaki, E., González-Rouco, J. F., Luterbacher, J., and Wanner, H.: Wet season Mediterranean precipitation variability: influence of large-scale dynamics and trends, Clim. Dynam., 23, 63-78, 2004.

Yevjevich, V.: An objective approach to definition and investigation of continental hydrological droughts, Hydrology Paper No. 23, Colorado State University, Fort Collins, Colorado, USA, 1967. 